\title{
QUALITY PASSENGER SERVICE IN AIR TRANSPORT AS A FOUNDATION FOR BUILDING LOYALTY TO AIR COMPANIES
}

\author{
Svetla Tzvetkova ${ }^{1}$
}

Received: 30.09.2020, Accepted: 20.10.2020

\begin{abstract}
All air companies in the world strive to build good image, preferences and loyalty in customers by offering then services that come as close as possible to their requirements. Most air carriers incorporate entire systems to secure the necessary quality; however, the solution to this problem is quite complicated and depends on multiple factors, especially the human one, which is why two perfectly identical services never exist in transport. For this purpose, air carriers need to build an overall strategy to improve services and outline the fundamental reference points of a plan for undertaking specific measures. The main reference point of said plan is a professional management team, as well as the motivation and timely training of highly qualified, responsible and courteous personnel that has an individual approach to all passengers and satisfies their consumer ideas for quality transportation to the fullest.
\end{abstract}

Keywords: passenger air transport, strategy for quality passenger service

JEL Codes: $R 40, R 41, R 49$

\section{Introduction}

Quality passenger service is a defining factor for increasing the competitive power of air companies in the vicious competitive conditions on the transport market. The quality of the transport service is a combination of properties which determine its fitness to respond to specific customer needs, in accordance with said customer's requirements (or the requirements set by standards and other regulatory documents). Commonly accepted standards for high-quality passenger service in air transport practically do not exist.

All services, including transport ones, are commonly characterized by variability in quality. Unlike material goods, there are no two perfectly identical

\footnotetext{
${ }^{1}$ Svetla Tzvetkova, University of National and World Economy, Economics of Transport Department, Assoc. Prof., PhD, e-mail: svetlatzvetkova@abv.bg ORCID ID: https://orcid.org/0000-0002-6499-5612
} 
transport services due to their heterogeneity and the fact that production in the field of transport is influenced by multiple and various factors. What should be taken into account in the development of the air transport product is that primary and accompanying services are never identical in quality. Therefore, certain differences always exist between seemingly identical services provided by the same transport firm - a fact which necessitates the individualization of the transport service, i.e. the need for an individual approach and quality attendance on behalf of employees toward each individual plane passenger. It is the only way for an air company to satisfy the individual needs of all consumers and strengthen their trust and loyalty.

Air carrier strategies for improving the service quality usually include the development of special programs designed to keep current customers. They identify the requirements and expectations of customers in the target segment and develop specific programs to satisfy their consumer criteria, additionally, analyzing identical services offered by their competitors and taking specific steps to continually improve staff qualification and training in the process.

The main purpose of quality passenger service in air transport involves maintaining and developing a stable customer base. It is defined by consumers' evaluation on the basis of qualitative indicators such as: professionalism, efficiency, approachability, courteousness, friendliness, honesty, empathy and readiness to assist in any situation on the part of employees. Quality service is aimed at mobilizing all resources and employees in the company toward fully satisfying customers' transportation needs. This effect is based on customers' positive attitude toward the company as gratitude for the professional service, loyalty. They are motivated to recommend the respective company's services to other people as well.

Quality service in air transport is determined entirely by customers' evaluation of transport services and it has a multiplicator effect, achieving effective marketing activity and increasing sales.

\section{Requirements for the Implementation of Services in Air Transport}

Services aimed at customers in air transport are required to: guarantee the safety of the passengers and their personal belongings; fulfill the requirements of aviation and fire safety, as well as sanitary and hygienic rules and norms; work in accordance with the requirements of the laws and regulatory documents regarding the range and conditions of service indicated in the agreements for ground service; guarantee passengers' comfort during travel. 
The services are provided by qualified personnel that need to be certified in accordance with established procedures.

The personnel providing passenger services are required to:

- guarantee passengers that they will receive friendly, courteous and timely attitude, as well as qualified help;

- observe the ethical standards for behavior and communication;

- strictly maintain the prescribed uniform and clean appearance;

- maintain high culture of speech, in accordance with their professional activities - questions and answers are short, the voice is level, elevated dialogue with unauthorized individuals is prohibited, no conversations are had in the office, and passengers receive an answer in the language they prefer.

All types of activities stipulated in the legislation are subject to licensing.

In-flight services for passengers provided by corporate bodies and organizations need to be certified, regardless of their organizational and legal form and form of ownership. The personnel in charge of organizing, carrying out, insuring and attending to passengers are required to have special training and certificate.

The timely realization of regular flights guarantees their safety, as well as commercial profitability for the air company; therefore, the managers and experts in charge of guaranteeing aircraft traffic regularity and flight safety need to be certified.

The services provided to passengers, as well as the terms of their implementation, are indicated on boards, monitors, posters and signs in brochures, announced through the broadcasted network, information desks at airports, ticket offices. Voice information needs to be clearly audible and understandable in all parts of airport terminals and adjacent territories. It needs to convey the message's meaning accurately, be timely and synchronized with passengers' registration process and preparation for each flight.

\subsection{Requirements for Aviation Services at Airports}

The procedure for providing services at the airport on a technological basis stipulates that they will be directly provided at places of work.

1. Support services by specially trained personnel for securing equipment and facilities:

- unaccompanied children and mothers with children;

- people with disabilities, ill and frail passengers;

- senior officials (VIPs);

- passengers from high service classes; 
- other, specially selected individuals.

2. Services (for additional charge) for transporting baggage from the airport's arrival zone for public and personal vehicles to the registration zone at the terminal or from the airport's baggage claim zone to the departure zone for public and personal vehicles;

3. If flights are delayed for 6 hours or longer, overnight, or for 8 hours or longer following the time indicated in the schedule, the passengers registered for the flight or on the basis of "OK" in their tickets will be accommodated in a hotel with food at the air company's expense. Regardless of their status and service class, the passengers registered for the flight or on the basis of "OK" in their flight tickets are supplied with food in case the flight is delayed for over 3 hours under the following conditions:

- flight delay time, and if a flight gets aborted, time needs to be determined for landing at an intermediate airport;

- local time is used to determine the type of food (breakfast, lunch or dinner).

4. The provision of soft drinks cannot be considered provision of food. Drinks are served to passengers who have been delayed for over 90 minutes.

In the event of a delay, the expenses for baggage storage at the terminal's baggage section or baggage room, which is located in the airport's customs zone, are covered by the air company.

5. Providing information about the option for hotel accommodations for passengers who have tickets with an "OK" sign for a period of no more than 24 hours before departure, with payment by the passengers.

6. Assisting passengers when receiving emergency and first aid at the airport's first aid stations.

7. Organizing passenger traffic through the airport:

- the length of the passenger road along the open platform in every direction should not exceed $50 \mathrm{~m}$ (from the waiting zone for departure at the airport's terminal to the bus, from the bus to the plane, etc.).

\subsection{Air Companies' Requirements Regarding Services Aboard the Aircraft}

Services aboard the aircraft are a combination of household goods, comforts and micro-climate, whose aim is to create specific physical and hygienic conditions for passengers and their maintenance by the flight attendants.

Operators need to guarantee that passengers aboard the aircraft are provided with a list of mandatory goods which is up to the established "Services 
for Passengers Aboard the Aircraft" standard and they are within their right to expand the range of the services on the basis of studying passengers' needs and requests, as well as IATA recommendations.

The terms and level of passenger service aboard the aircraft are provided by air companies:

- compartment equipment and interior;

- technical devices and systems which guarantee passenger safety and create comfort inside the cabin;

- the sanitary and hygienic condition of the passenger cabin, the servicing and maintenance of the buffet-kitchen equipment, passenger service items and elements;

- securing seats that allow the use of cradles for passengers with children;

- option for comfortable accommodation of ill passengers/people with disabilities;

- items for personal use (individual lighting, ventilation, small tray table, a safety belt system, oxygen masks, emergency life vests);

- a guaranteed selection of services suited to the duration of the flight;

- competent and tactful actions by the flight and cabin crew.

\section{Problems Related to Passenger Service in Air Transport}

As a qualitative characteristic of the air company product, customer service has several stages:

- ticket sale service;

- service at the airport;

- service aboard the aircraft.

It is difficult to secure the level of service that the air company desires when it comes to ticket sales due to the large variety and multitude of sales channels. In most cases about two thirds of the tickets are sold as a result of the activity of air company agents. The majority of the sales volume is realized by other air companies, whereas the rest is realized in the air company's personal offices (the so-called personal sales).

Due to the nature of the established ticket sale system, air companies face multiple problems, the biggest of which include:

- Inconsistent passenger flow which is influenced by seasonal and daily fluctuations;

- The large flow of vacationers aims to purchase tickets at the lowest possible prices; 
- The necessity to refund customers for tickets they have already purchased in case a flight has been cancelled due to reasons outside the company's control;

- Competitive air companies which offer a multitude of special and promotional prices.

In order to solve all these issues, companies incorporate modern automated seat reservation systems which provide information for all prices and any changes to them.

The automated ticket reservation systems are used precisely because they allow passengers to reserve seats aboard an aircraft at any moment and pay for the tickets on the respective day along the selected direction.

Regular flights are among the services for which the utilization of a reservation system is imperative. Passengers need to be sure about the purchased tickets for each flight since every air company always has replacement aircraft with a crew ready to carry out a flight if the demand is high.

The main disadvantages of this type of flights include:

- possible inconsistencies in schedules;

- extended passenger stay in preparation for a flight;

- a small number of flight hours per airplane;

- the necessity to create additional crew lists for short-distance flights.

As far as the issue of unused reserved tickets is concerned, the reasons could be random, i.e. illness, late arrival at the airport or the occurrence of an incident or emergency situation, as well as non-random - for instance, a businessman who is unaware of the exact time when a certain meeting will conclude and has simultaneously reserved several flights in advance. In order to fill all available seats, air companies need to make super-reservations, i.e. reserve more seats than the number of available ones in the aircraft. For this purpose, air carriers usually collect statistical information and analyze calculations about the average quantity of refusals for specific periods from the year.

After all, the possibility that all passengers who have reserved seats aboard the respective flight will appear should be taken into account. Air companies determine this in the final minutes prior to the flight and are forced to deny business passengers a flight at the expense of late arrivals for flight registration. The failure of a planned business undertaking causes businessmen to protest and in turn leads to their refusal to use the respective air company's services in the future. 
Because of this, air companies select several passengers traveling for vacation as part of an individual program, warn them about the possible cancellation of their flight and offer them a choice between:

- choosing a flight on another day in a lounge with higher level of service;

- refunding the paid ticket sum, as well as certain financial compensation for any experienced inconveniences.

A large portion of travelers prefer to receive money and move their flight to another day in the same class.

Businessmen who arrive at the airport immediately before the flight demand that airport service be at the necessary level:

- to use a separate flight registration desk and carry their luggage into the airport lounge;

- to await their flight in a separate room with office equipment;

- to board the plane through a separate corridor for business passengers;

- to have available parking space at the airport from which they depart, as well as the respective service and secured transportation from the airport when they arrive.

Servicing businessmen at the desired level results in additional expenses for airports, which in turn increases the price of its functioning and ticket prices respectively.

Ticket demand by businessmen is at its highest for morning and evening hours on work days, whereas demand by vacationers is at its highest during weekends. This irregularity in demand forces air carriers to use additional aircraft during peak periods when airports work with higher capacity and require larger personnel and production resources. During periods when there are drops in demand, both air companies and airports have unused production capacity and free personnel, which leads to increased prices.

Aboard the aircraft passengers are served food and drinks and entertainment programs are made available to them. All the same, though, the main expenses of air companies in regard to security and service aboard the aircraft are the payment of the crew and the costs for their hotel accommodations.

Problems involving the management of customer service quality are frequent as well. Managers from the middle sections of the company could be put in charge of improving the service and expanding the powers of line contractors, as well as assign more power to their subordinates in order to satisfy customers' needs. The encouragement of managers needs to be bound to the results from the customer service, on the basis of constant and objective evaluation. Managers' power is expanded when they are also put in charge of mobilizing human 
resources in order to achieve results. The main goal of managers is aimed at creating new conditions for people who work directly with customers to make decisions. It is precisely middle-section managers who carry the full responsibility for achieving the set goals regarding service.

\section{Inferences and Recommendations}

Air companies need to pay special attention to airport service, even though they are unable to have complete influence over that. Therefore, even if there are insignificant oversights in airport service (i.e. untimely ramp service, baggage delay), passengers often associate them with the air company's work.

On-board attendance is the main part of the service that air companies provide passengers with. Once they have purchased their tickets, passengers need to know what they will receive for it: whether they will have food on board or not, what assortment of dishes there will be, what additional services they will be offered, etc. When they spend several hours in the limited space aboard the plane, sitting in narrow and uncomfortable sets, passengers only think about how to pass the time. Therefore, the organization of free time aboard the plane should not be limited (as is often the case) to press distribution, which is still not always sufficient. At the very least, long-distance air companies should provide additional type of on-board entertainment (audio, video) despite all the difficulties involving the conversion of Russian airlines.

Some airlines view on-board food is an important factor whereas others do not see it as that essential. In spite of this, passengers consider it one of the fundamental indicators that help them assess an air company and its services. There is practically no information about feeding aboard a plane. Pictures and descriptions of offered dishes published on certain airlines' websites pertain mainly to international flights. Saving food (i.e. cake or an extra cup of juice) could have a negative effect on the airline's overall image. It is necessary to save the airline some resources, but in other positions for the expenses of the entire stage of the travel organization.

In order to understand passengers' ideas regarding service quality, air carriers need to know and foresee their preferences and expectations and receive feedback from them. This can be achieved not only through studies, but also with the help of other channels, i.e. telephone lines, quality control data and other services which have direct contact with consumers. Even if they use an air company's services once per year, all passengers need to be familiar with these channels. In order to maintain the necessary level of quality or improve it, air companies need to carry out regular market studies and research passengers' 
needs. The achievement of high-level passenger service increases an air company's competitive power and helps it stand out from other carriers on the transport market.

At present, the following view on the issue of quality improvement has been universally acknowledged in all developed countries: no episodic, separate, even brilliantly organized and major event can guarantee significant improvement of the product's quality; the solution to this problem requires a system of purposeful and systematic measures or a quality management system. If the quality system is a combination of organizational structure, responsibility, procedures, processes and resources that guarantee the realization of general management of the quality of an airline's production activities, it can be examined as a combination of interlinked systemic organizational, technical, economic, legal, social and information measures, methods and resources regulated by the regulatory documents aimed at the systemic, systematic improvement of the aviation enterprise, as well as the increased effectiveness and quality of the air company's production activities.

It is recommended that air companies develop a service plan on the basis of a customer service strategy which is built on a clear vision for the corporate goals in the field of customer service, as well as a sensible and logical plan for achieving said goals. The strategy should include: characteristics of the customer base; customer evaluation on the various aspects of service; assessment of costs for increasing the level of customer satisfaction; prognosis for profit growth. The plan should be part of a completely new and different marketing plan.

The principles for its development are as follows:

- to promise less and to do more;

- to correctly determine customers' expectations;

- to study customers' needs and questions carefully;

- to make it clear that only the customers know what they want;

- to divide the market into segments and develop the fundamental products and services which will satisfy customers' individual needs due to the fact that customers can purchase the same product or service, but their needs during attendance can be different.

The recommended methods for studying service quality include:

- informal questions for the personnel;

- formal questions for focus groups;

- questions for associates and external consultants;

- free telephone lines;

- polls by post (phone), cards regarding customer feedback; 
- control programs for deals that have not been concluded yet;

- analysis of the responses and sales volume of key customers;

- accounts of inspected complaints;

- video recordings of interviews conducted with focus groups.

The regular collection of information from customers (inquiries and polling of customers) about their evaluation of the service quality and the degree of their satisfaction from the undertaken actions allows the determination of personnel work, as well as the ease of access to companies and their services. Additionally, the necessary time for solving typical problems can be determined, as well as the degree to which customers can attract personnel attention if necessary and cause a reaction in them, and how accurate, complete and effective that reaction would be.

The organizational activity which involves providing customers with quality service in air transport should be comprised of:

- developing a strategy and a plan for service;

- direct leadership participation (first meeting under the supervision of the general manager, following seminars for managers, objectives and plans of subdivisions, control over plan implementation and personnel training);

- highly qualified and motivated attending personnel;

- high quality of the services offered by employees;

- available maintenance infrastructure in the air company;

- incorporating a monitoring procedure and systemic evaluation of the quality of the air company's customer service.

It should be noted that air companies' associates and partner companies providers of services, should display resourcefulness and enthusiasm, otherwise the point and strategy of the service plan are lost. Associates should be assigned certain powers and be allowed to do everything necessary in regards to customer service - to the customer's benefit, not the company's. Training is a mandatory condition for the assignment of powers, which itself is a crucial condition for creating high culture of passenger service in air transport.

Marketing specialists in transport services often face the dilemma of how to provide standardized transport services at a good quality level, acceptable prices and simultaneously be competitive enough to approach each individual customer as a unique individuality. In order to secure control over quality, it is recommended that air carriers adopt a number of measures; first and foremost, of course, the rolling stock should be kept in good technical condition and enough resources should be set aside for the proper training of the personnel and the 
recruitment of qualified workers. Attending personnel should be cultured, wellmannered and good-looking. The creation of a "complaints and suggestions" system also leads to good results, since it allows air companies to keep track of cases of customer dissatisfaction and to take timely measures for the elimination of flaws in the implementation process of the transport service itself.

\section{Conclusion}

In recent years the competition on the air transport market has grown vicious and consumers' marketing criteria are ever-changing due to the influence of various environmental factors. In order to successfully maintain their positions on the transport market and stand out among the competition, air carriers need to aim towards developing new services, as well as keep a constant watch on the improvement of the services they already provide.

Improving the quality of passenger service in air transport should be one of the primary goals of air companies. The current vicious competitive conditions necessitate a new and different way of thinking which focuses not on profit as an end in itself, but rather on fully satisfying customers' needs. Achieving highquality service as an immaterial asset increases market capitalization. High personnel effectiveness is guaranteed when they receive acknowledgment for doing their job well. The building and strengthening of an air company's reputation as an appealing employer that secures stable work pay, career growth and social protection creates opportunities for attracting good experts and highly qualified personnel. Passenger air transport businesses should hire employees who love people and are motivated to work and improve their skills. The principle for creating a system for moral encouragement such as additional financial support and bonus payments for work experience, sincere recognition, timeliness and publicity is crucial to the development of air carriers. The good reputation of the air company will guarantee stability and security for employees, which in turn will lead to reduced fluctuation and increase employment productivity. Good service and customer satisfaction are key conditions for creating brand loyalty which in turn determines whether a company would be able to maintain and even increase its market share. 


\section{REFERENCES}

Авиатрансагентство; (2020) Web site: www.aviatrans.ru;

Фонд развития инфраструктуры воздушного транспорта «Партнёр гражданской авиации»;(2020) Web site: http://www.aviafond.ru/aviation;

transport.ru (2020) Web site: www.transport.ru;

AO «Эксперт PA»; (2020) Web site:

http://www.raexpert.ru/researches/avia/part2/;

KrasAir (2013) Web site: http://www.krasair.ru;

Журнал БТИ - Бюллетень транспортной информации, рефераты статей o перевозках всеми видами транспорта (2020) Web site: www.natrans.ru;

gruzotransport.ru (2020) Web site: http://gruzotransport.ru/2009/10/06/tendencii razvitija_vozdushnogo trans porta rossii.html. 